\title{
Основи модернізації публічного управління: регіональний аспект
}

\begin{abstract}
У статті приділено увагу державному програмно-иільовому стратегічному управлінню регіональним розвитком, яке запропоновано розглядати у вигляді управлінського циклу, щчо забезпечує послідовну взаємодію програми розвитку, метою якої є якісні перетворення у сочіально-економічній системі, та програмно-цільового бюджетування, орієнтованого на адаптацію суб'єкта публічного управління - виконавчої гілки влади - до цих перетворень. Послідовно розкрито положення, що за допомогою такої взаємодії реалізується дуже важлива інституційна функція програми регіонального розвитку, щчо полягає не тільки в досягненні, але $i$ в подальшому регулярному відтворенні ї̈ результатів. Обтрунтовано, щчо податкова децентралізація є невід'ємною умовою створення платформи для ефективного забезпечення платоспроможності регіонів і місиевого самоврядування, стійкого економічного та сочіального розвитку територіальних громад, якісного та ефективного надання публічних послуг їхнім мешканиям.
\end{abstract}

Ключові слова: децентралізація; публічне управління; регіональний розвиток; соціальноекономічна система; стійкий розвиток.

В умовах високого рівня централізації бюджетно-податкових повноважень стабільність соціальноекономічного розвитку України залежить багато в чому від спроможності держави враховувати реальні проблеми розвитку регіонів, стимулюючи їхній внутрішній потенціал, а також від узгодженості дій у системі управління «центр - регіони та місцева влада». Традиційно основним інструментом реалізації державної політики соціально-економічного розвитку в Україні є різноманітні форми (програми та проєкти) програмно-цільового управління. Під час реформи бюджетного процесу (бюджетної децентралізаціі) відбувається послідовне впровадження програмно-цільового бюджетування у практику державного управління. У зв'язку з цим виникає два актуальні науково-практичні завдання. По-перше, це вивчення можливостей та наслідків поєднання у державній програмі функцій інструменту програмноцільового бюджетування та документа стратегічного планування. По-друге, дослідження проблеми узгодження процесу розробки, орієнтованої на довгострокову перспективу розвитку державної програми та процесу середньострокового бюджетного планування, що має високу інерційність.

Також відбувається переформатування діяльності органів виконавчої влади - розробників державних програм на основі концепції проєктного управління, що потребує додаткових теоретичних досліджень, зокрема уточнення предметних сфер проєктного та програмного управління, ролі проєктів у структурі програм регіонального розвитку.

Аналіз досліджень і публікацій. Теоретико-методологічні основи розвитку програмного управління та бюджетування розглянуто в роботах Е.Афоніна, В.Бабаєва, І.Бистрякова, К.Ващенка, С.Домбровської, І.Драгана, І.Ібрагімової, В.Князєва, В.Козакова, Н.Липовської, А.Ліпенцевої, Т.Маматової, В.Микитенко, Н.Нижник, О.Оболенського, П.Петровського, М.Рудакевич, Е.Сергієнко та ін.

Мета статті - розкрити зміст загальних методичних положень щодо реалізації процедур державного програмно-цільового стратегічного управління регіональним розвитком.

Викладення основного матеріалу дослідження. Регіональна політика колишнього СРСР до кінця 1980-х рр. здійснювалася в умовах адміністративно-планової системи централізованого управління та екстенсивного економічного розвитку, що вплинуло на характер проблем управління регіональним розвитком.

Розробка програмно-цільових методів планування та управління в СРСР протягом 1970-1980-х рр. здійснювалася у межах масштабної роботи з удосконалення системи планування та управління народним господарством. Їх використання мало сприяти подальшому зростанню національного добробуту за рахунок «переходу на інтенсивний шлях розвитку, при якому збільшення національного доходу буде досягатися не на основі випереджального зростання капітальних вкладень, а за рахунок підвищення їх ефективності, більш раціонального використання виробничого потенціалу» [4, с. 12-13].

До основних завдань, що вирішувалися за допомогою програмно-цільового підходу, варто зарахувати: запобігання відомчій роз'єднаності, що сприяє неузгодженню цілей, темпів та пропорцій соціально-економічного розвитку; взаємопов'язання різних аспектів розвитку галузей та територій при

() Л.Я. Самойленко, I.В. Драган, 2021 
вирішенні складних проблем соціально-економічного розвитку; подолання інерційності, яка «притаманна розвитку будь-якої, навіть оптимально організованої, господарської системи».

Одне із найважливіших теоретико-методологічних питань, що виникли під час активної розробки програмно-цільових методів планування та управління в народному господарстві колишнього СРСР, полягає у визначенні ролі та місця програм у системі народногосподарського планування. Оскільки процес розробки програм розглядався ізольовано, на відміну від складання планів розвитку народного господарства, галузей, відомств і територій, необхідно було вирішити завдання побудови єдиної процедури планування, що забезпечує взаємоузгодження плану та програми.

Відтак щодо співвідношення програм та довгострокового плану розвитку народного господарства у літературі були представлені дві протилежні точки зору. Згідно з першою з них, викладеною в роботі [8], довгостроковий план має бути сукупністю народногосподарських програм, які орієнтовані на задоволення основних функціональних потреб суспільства, що, на думку авторів, було необхідно для подолання таких принципових недоліків галузевого принципу планування: недостатня цілеспрямованість планів на досягнення кінцевих цілей соціально-економічного розвитку; неможливість у межах існуючої системи планування досить повно та точно встановлювати співвідношення потреб у ресурсах між взаємопов'язаними галузями, яке здатне породжувати диспропорції та зниження ефективності їхньої роботи; відсутність стимулів до пошуку оптимальних шляхів задоволення тих самих потреб за наявності альтернативних джерел енергії, сировини та матеріалів.

Така позиція авторів базувалася на міжгалузевому підході до вирішення проблем національної економіки, запропонованому у [9]. У наведених роботах доводиться доцільність застосування основ системного аналізу та програмного підходу при виділенні як об'єкта управління міжгалузевих народногосподарських комплексів. Показано, що у народному господарстві об'єктивно існують багатогалузеві комплекси, структурні елементи яких пов'язані єдністю мети.

Відповідно до іншої, найбільш поширеної точки зору, програми мають розроблятися для вирішення обмеженого кола проблем соціально-економічного розвитку. За такого підходу у плані виділяється відповідна програмна частина [2, с. 177].

Звісно ж використання другого підходу було найбільш реалістичним, оскільки обмежена кількість локалізованих у часі та просторі програм не покривала всю сферу народного господарства. Тобто, народногосподарське планування (довгострокове, п’ятирічне, галузеве, територіальне) було постійною функцією відповідних органів планування, що передбачало високий рівень інерційності планового процесу.

Наступним етапом у розвитку методології програмно-цільового планування та управління стає перехід від розробки та реалізації розрізнених цільових комплексних програм до побудови їхньої взаємопов'язаної системи в адміністративно-територіальному розрізі. Актуальність синтезу цільових комплексних програм автор [3, с. 152] доводить не тільки їх великою кількістю на рівні союзної республіки, а й тим фактом, що «синтез є елементом процедур розробки програм», що дає змогу вирішувати глобальні цілі соціально-економічного розвитку. Розвиток концепції нелінійного розвитку регіональної системи, одним із найважливіших факторів якого є науково-технічний прогрес, автор говорить про необхідність наявності у господарському механізмі управління трьох складових, що відіграють різну роль у фазах розвитку технологічних укладів: у першій фазі - програмно-цільовий механізм управління розробкою та реалізацією синтез-програми; в другій фазі - програмно-цільовий механізм управління, спрямований на стимулювання нового та нівелювання старого технологічного укладу, у третій фазі - традиційний механізм, що передбачає децентралізацію та орієнтується на потреби ринку. В цілому у роботі показано здатність керованої з єдиного центру синтез-програми до реалізації революційних змін, таких як зміна технологічних укладів, забезпечення перехідного процесу, тоді як у межах окремих цільових комплексних програм забезпечується еволюційний розвиток мезоекономічної системи.

Таким чином, у радянський період вітчизняними вченими була успішно вирішена наукова проблема узгодження цілей та ресурсів за допомогою виділення як об'єкта планування та управління міжгалузевих та територіально-виробничих комплексів та, відповідно, розробки й реалізації комплексних міжгалузевих і регіональних цільових програм.

Внаслідок переходу до ринку кардинальні зміни відбулися у самій конструкції «програма - план бюджет». I якщо в умовах планового господарства колишнього СРСР бюджетне планування було підпорядковане плануванню народногосподарської діяльності, то в сучасних умовах, коли останнє було скасовано, бюджетний механізм залишився єдиним інструментом реалізації державою планових функцій.

Однією з особливостей регіональної політики у пострадянський період став відхід від врахування проблемного економічного районування, що суттєво впливає на зміст програм розвитку, та акцент на вирівнюванні рівнів соціально-економічного розвитку регіонів України. Незатребуваною у державному управлінні регіональним розвитком залишається запропоноване науковцями ДУ «ІЕПСР НАН України» 
групування регіонів України за фактором «відносно високий», «відносно середній» та «відносно низький», де дослідниками здійснено зіставлення визначених вимірів і характеристик саме задля ідентифікації реального сектору національної системи управління в межах внутрішнього виробничогосподарського середовища [1, с. 33-56].

На жаль, модель міжбюджетних відносин, що діє в Україні, довгий час не формує на регіональному рівні стимулів до сталого розвитку, економічною передумовою якого є зростання їх податкової бази i, отже, бюджетної самозабезпеченості [3, с. 150].

Тут необхідно пояснити, що низька бюджетна забезпеченість регіонів є наслідком як об'єктивних умов, зумовлених відмінностями природного, географічного і ресурсного характеру, а й суб'єктивних чинників, таких як високий рівень корупції, тіньової економіки, низька ефективність державного управління та інших.

Автором запропоновано селективний підхід до визначення бюджетно-податкових умов збалансованого розвитку регіонів, що нівелюють їх дотаційність. У межах цього підходу розроблено методику визначення нормативів розподілу податкових надходжень 3 ПДВ між державним та регіональними бюджетами, засновану на зіставленні обсягу дотації регіональному бюджету з розміром ПДВ. При цьому, грунтуючи свої розрахунки на припущенні, що «14 \% (25 лютого 2021 р. прийнято зміни до Податкового кодексу України відносно зниження ставки ПДВ з 20 \% до 14 \%) обсягу ВРП щорічно йде до державного бюджету», автор насправді прив'язує регіональну частку відрахувань 3 ПДВ лише до величини ВРП.

Однак цей підхід не враховує таких факторів, як нерівномірність локалізації ПДВ на економічному просторі України, фактична частка ПДВ у структурі податкових доходів регіонів, регіональний рівень тіньової економіки та структура ВРП, що ускладнює досягнення поставленої у статті мети стимулювання регіонального розвитку.

Як зазначено у роботі [5], досягти збільшення ефективності надання публічних благ за рахунок децентралізації можливо лише «за відсутності екстерналій та опортуністичної поведінки субнаціональної влади стосовно центральних органів влади».

Однак пропозиція авторів використовувати отримані результати для обгрунтування розширення обсягів міжбюджетних трансфертів, що надаються регіонам, доцільно лише на якісно іншій основі міжбюджетних відносин.

Певним кроком у цьому напрямі стало використання у методиці розрахунку міжбюджетних трансфертів принципу пропорційного підтягування доходів дотаційних районів до середньоукраїнського рівня. Однак необхідно визнати, що такий підхід, хоча і вносить елемент справедливості в систему розподілу міжбюджетних трансфертів, все ж таки сам собою не здатний помітно впливати на вирішення специфічних проблем розвитку регіонів у межах системи бюджетної децентралізації, що склалася, а також не враховує їхню соціально-економічну неоднорідність.

Для цього необхідно розробити якісно іншу концепцію регіональної політики. Конструктивною $є$ пропозиція не вирівнювати, а підтримувати соціально-економічну рівновагу між зонами та регіонами на основі підвищення ефективності [7, с. 47-52]. Вирішення цього завдання автор пропонує забезпечити за допомогою додавання до регіональної політики принципової схеми розподілу сукупного суспільного продукту та врахування реалізації трьох послідовних стадій. Спочатку на основі диференційованого загальнодержавного комплексного соціального стандарту умов життя в регіонах необхідно забезпечити «мінімальні критерії доступної різноманітності та якості громадських послуг». На другому етапі подальше зростання добробуту в регіоні залежить від успіхів цього регіону в економічному розвитку. I, нарешті, на подолання актуальних проблем спрямоване цільове прискорення соціального розвитку регіонів, яке передбачає, по суті, програмно-цільове управління регіональним розвитком.

На підставі викладеного вище стає цілком очевидно, що поступова децентралізація податкових повноважень здатна стати дієвим інструментом регіональної політики лише в межах підходу, що поєднує вирівнювання $з$ підвищенням ефективності та відповідальності, що сприяє появі в регіонах стійких стимулів до розвитку власної податкової бази.

Іншим інструментом державного управління регіональним розвитком, який набув поширення 3 початку 1990-х рр., стали державні цільові програми розвитку регіонів. Однак необхідно визнати, що зміст заходів та результати реалізації програми найчастіше суперечили концепції програмно-цільового методу як способу обгрунтування та вирішення актуальних проблем, що стримують розвиток соціальноекономічної системи.

На особливу увагу заслуговує аналіз ролі та місця програм розвитку в системі національного стратегічного планування. В національній доповіді «Соціально-економічний потенціал сталого розвитку України та їі регіонів: вектори реального поступу» [6] робиться важливий висновок про те, що одним із важливих факторів ефективного стратегічного планування $є$ узгодження територіальних та галузевих інтересів. По суті, у цій роботі пропонується нова концепція політики регіонального розвитку, спрямована на те, щоб об'єднати два підходи, відповідно до одного 3 яких акцентується увага на 
регіонах - лідерах економічного розвитку, а відповідно до іншого - реалізується традиційна політика економічного вирівнювання. Таким чином, у межах запропонованої концепції «традиційне економічне вирівнювання дедалі більше стає закономірним результатом позитивного вирівнювання економіки України як простору інноваційного розвитку». При цьому, щоб інноваційна модернізація публічного управління стимулювала регіони до розвитку, поряд із вирішенням завдань структурної перебудови та підвищення конкурентоспроможності вітчизняної економіки, зростання добробуту та якості життя ії населення, на думку авторів, вітчизняна система стратегічного планування має, по-перше, бути селективною, а по-друге, передбачати вдосконалення економіко-правових засад української державності, насамперед міжбюджетних відносин та децентралізації управління.

Таким чином, наразі єдиним інструментом вітчизняної регіональної політики залишається вирівнювання рівнів бюджетної забезпеченості. При цьому невирішеним залишається завдання підвищення податкової бази регіонів. Ця обставина потребує вивчення вітчизняного та зарубіжного досвіду використання форм програмно-цільового управління соціально-економічним розвитком. Так основна увага надалі має бути приділена проблемі узгодження програми та бюджету і відповідно зіставленню принципів програмно-цільового планування та управління й програмно-цільового бюджетування.

Висновок. Розглянуто вітчизняний досвід державного управління регіональним розвитком. Встановлено, що $з$ початку 1990-х рр. в Україні бюджетний процес стає головним інструментом реалізації державою планових функцій. В умовах високого ступеня централізації бюджетно-податкових повноважень, а також низької бюджетної забезпеченості більшості вітчизняних регіонів державна регіональна політика полягає головним чином у вирівнюванні рівнів соціально-економічного розвитку. Однак, як показав огляд наукових робіт, присвячених регіональним дослідженням, політика центру, що реалізується за допомогою міжбюджетних трансфертів, не значно впливає на соціально-економічний розвиток регіонів України.

Доведено, що податкова децентралізація є невід'ємною умовою створення платформи для ефективного забезпечення платоспроможності регіонів та місцевого самоврядування, стійкого економічного та соціального розвитку територіальних громад, якісного та ефективного надання публічних послуг їх мешканцям. Досягнення наведеної мети передбачає цілеспрямоване забезпечення послідовності та передбачуваності фіскальної та бюджетної політики. Доведено, що успішна реалізація видаткових зобов'язань місцевих бюджетів у сформованих умовах податкової децентралізації потребує реформування бюджетного процесу та фіскальної системи, що уможливить прогнозованість фінансових ресурсів місцевого самоврядування.

\section{Список використаної літератури:}

1. Алимов О.М. Системно-комплексне оцінювання потенціалу сталого розвитку України / О.М. Алимов, В.В. Микитенко, I.М. Лииур. - К. : ДУ ІЕПСР НАН України, 2013. - 88 с.

2. Ващенко К.О. Постмодернізація публічної служби в країнах ЄС / К.О. Ващенко, О.В. Онуфрієнко, C.M. Серьогін // Публічна служба: системна парадигма : кол. монограф. ; заг. ред. С.М. Серьогіна. Дніпро : ДРІДУ НАДУ, 2017. - С. 177-191.

3. Даудова Г.В. Бюджетоутворюючі податки місцевих бюджетів в контексті бюджетної децентралізації / Г.В. Даудова // Теорія та практика державного управління : зб. наук. пр. - Х. : Вид-во ХарРІ НАДУ «Магістр», 2015. - Вип. 3 (50). - С. 150-156.

4. Державна регіональна політика України: особливості та стратегічні пріоритети : монографія / за ред. 3.С. Варналія. - Київ : НСД, 2007. - 820 с.

5. Карташов С.Г. Основи публічного правління та антикорупційна діяльність : навч. посіб. / Є.Г. Картамов, І.О. Драган, А.В. Антонов. - Київ : Освіта України, 2020. - С. 122-132.

6. Лібанова Е.М. Соціально-економічний потенціал сталого розвитку України та їі регіонів: вектори реального поступу : національна доповідь / Е.M. Лібанова, М.А. Хвесик, I.В. Драган. - К. : ДУ ІЕПСР НАН України, 2017. $-864 \mathrm{c}$.

7. Микитенко B.B. Формування механізмів управління забезпеченням сталого господарювання / B.В. Микитенко, І.В. Драган, І.О. Драган // Економіка, управління та адміністрування. - 2021. - № 3 (97). C. $47-52$.

8. Овчарук В.В. Впровадження і використання конкурентних переваг регіону / В.В. Овчарук, Т.Є. Удовиченко [Електронний pecypc]. http://www.nbuv.gov.ua/old_jrn/natural/Vnulp/Menegment/2010_691/58.pdf.

9. Щодо інструментів розкриття «точок зростання» у стратегіях соціально-економічного розвитку регіонів : аналітична записка [Електронний ресурс]. - Режим доступу : http://www.niss.gov.ua/articles/354.

\section{References:}

1. Alymov, O.M., Mykytenko, V.V. and Lycur, I.M. (2013), Systemno-kompleksne ocinjuvannja potencialu stalogo rozvytku Ukrai'ny, DU IEPSR NAN Ukrai'ny, K., 88 p. 
2. Vashhenko, K.O., Onufrijenko, O.V. and Ser'ogin, S.M. (2017), «Postmodernizacija publichnoi' sluzhby v krai'nah JeS», Publichna sluzhba: systemna paradygma, kol. monograf, in Ser'ogin, S.M. (ed.), DRIDU NADU, Dnipro, pp. 177-191.

3. Daudova, G.V. (2015), «Bjudzhetoutvorjujuchi podatky miscevyh bjudzhetiv v konteksti bjudzhetnoi' decentralizacii'», Teorija ta praktyka derzhavnogo upravlinnja, zb. nauk. pr., Vyd-vo HarRI NADU «Magistr», Harkiv, Issue 3 (50), pp. 150-156.

4. Varnalija, Z.S. (ed.) (2007), Derzhavna regional'na polityka Ukrai'ny: osoblyvosti ta strategichni priorytety, monografija, NSD, Kyi'v, 820 p.

5. Kartashov, Je.G., Dragan, I.O. and Antonov, A.V. (2020), Osnovy publichnogo pravlinnja ta antykorupcijna dijal'nist', navch. posib., Osvita Ukrai'ny, Kyi'v, pp. 122-132.

6. Libanova, E.M., Hvesyk, M.A. and Dragan, I.V. (2017), Social'no-ekonomichnyj potencial stalogo rozvytku Ukrai'ny ta i'i' regioniv: vektory real'nogo postupu, nacional'na dopovid', DU IEPSR NAN Ukrai'ny, K., 864 p.

7. Mykytenko, V.V., Dragan, I.V. and Dragan, I.O. (2021), «Formuvannja mehanizmiv upravlinnja zabezpechennjam stalogo gospodarjuvannja», Ekonomika, upravlinnja ta administruvannja, No. 3 (97), pp. 47-52.

8. Ovcharuk, V.V. and Udovychenko, T.Je. (2010), Vprovadzhennja i vykorystannja konkurentnyh perevag regionu, [Online], available at: http://www.nbuv.gov.ua/old_jrn/natural/Vnulp/Menegment/2010_691/58.pdf

9. www.niss.gov.ua (2011), Shhodo instrumentiv rozkryttja «tochok zrostannja» $u$ strategijah social'noekonomichnogo rozvytku regioniv, analitychna zapyska, [Online], available at: http://www.niss.gov.ua/articles/354

Самойленко Лариса Яківна - кандидат наук з державного управління, доцент кафедри державної служби, публічного адміністрування та політології Черкаського національного університету імені Богдана Хмельницького.

https://orcid.org/0000-0002-0335-3077.

E-mail: larisa1477@ukr.net.

Драган Ірина Василівна - доктор наук з державного управління, старший науковий співробітник відділу методології сталого розвитку ДУ «Інститут економіки природокористування та сталого розвитку НАН України».

https://orcid.org/0000-0002-6906-5000.

Наукові інтереси:

- модернізація публічного адміністрування.

Стаття надійшла до редакції 15.11.2021. 